\title{
ANALISIS PENERAPAN PSAK NO. 45 TENTANG PELAPORAN KEUANGAN ENTITAS NIRLABA PADA PANTI ASUHAN AL-HUSNA BUKIT PAMULANG INDAH
}

\author{
Eka Kusuma Dewi ${ }^{1}$, Muliyani ${ }^{2}$ \\ Universitas Pamulang \\ email: eka.kusuma.dewi@gmail.com
}

\begin{abstract}
This research is based on observations at the Al-Husna Orphanage at the Al-Husna Foundation in the Bukit Pamulang Indah Complex. Alpha fourteen. Pamulang Timur District. Tangerang Selatan Banten Province, foster children numbered thirty-five people with a total of twenty-six administrators. Foster children consisting of orphans do not have a father as head of the family and some are from poor families. Foster children in the range of education from elementary schools, junior high schools to high schools. The foster children are helped from school fees up to the day-to-day costs, but for their homes they are still cared for by their respective families. Every month they are gathered at the Masjid Al-Muhajirin Bukit Pamulang Indah Complex to monitor their educational development, their grades at school together with the provision of monthly compensation. For children who have achievements, the Al-Husna orphanage also gives prizes every semester with the aim of providing motivation to continue to perform and also to encourage his friends to achieve achievements as well. Once a year the foster children are also invited to travel with caregivers so they are happy and happy, such as to the top, to Bandung, and others. Meanwhile, the management consists of 26 residents from the area around the beautiful Pamulang hill complex in South Tangerang. These mothers come from different work backgrounds. There are housewives, employees, and who have their own businesses. Management is voluntary, without payment or salary. They really only aim to worship to help others. So far the Al Husna Orphanage in South Tangerang has received funds from permanent donors and donors. They have been keeping financial records simple. None of the administrators has a special ability to do bookkeeping. They simply record the income received from donors and expenses for their foster students. The purpose of this study is to look at financial reporting that has been carried out by the treasurer of the Al-Husna orphanage foundation. Furthermore, compile its financial reporting in accordance with PSAK standard no.45 regarding the financial reporting of non-profit organizations. Because the Orphanage is an organization that is not looking for profit, then PSAK 45 is in accordance with the nature of their organization. It is expected that by applying PSAK 45 for the preparation of their financial reports, financial accountability and transparency can be created so that they can be held accountable to foundations, donors and the public. This type of research uses descriptive qualitative research, with the steps of data collection, data processing or data analysis, preparation of reports and drawing conclusions.
\end{abstract}

Keywords: Organization, non-profit, PSAK 45 


\section{PENDAHULUAN}

\section{Latar Belakang}

Laporan keuangan organisasi nirlaba tentu berbeda dengan laporan keuangan organisasi bisnis pada umumnya. Perbedaan yang utama ada pada bagaimana cara organisasi memperoleh sumber daya yang dibutuhkan untuk melakukan berbagai aktivitas operasinya. Organisasi nirlaba memperoleh sumber daya yang berasal dari sumbangan para anggota dan para penyumbang lain yang tidak mengharapkan imbalan apapun dari organisasi nirlaba tersebut. sumbangan-sumbangan tersebut didapatkan berdasar atas jasa yang diberika oleh organisasi tersebut. (Dinanti dan Nugraha, 2018) PSAK 45 tentang pelaporan keuangan entitas nirlaba. Entitas nirlaba dalam hal ini organisasi nirlaba merupakan organisasi yang bersifat tidak mencari laba. Oleck \& Stewart menyatakan bahwa entitas nirlaba atau dapat juga organisasi nonprofit adalah organisasi atau badan yang tidak menjadikan keuntungan sebagai motif utamanya dalam melayani masyarakat atau juga disebut sebagai korporasi yang tidak membagikan keuntungannya sedikit pun kepada para anggota, karyawan, serta eksekutifnya (Afifah, 2019). Sumber daya yang diperolehpun bukan berasal dari hasil keuntungan. Entitas nirlaba memperoleh sumber daya dari sumbangan para anggota dan para penyumbang lain yang tidak mengharapkan imbalan apapun dari organisasi tersebut (IAI, 2015). Menurut Kamus Besar Bahasa Indonesia (KBBI) Panti asuhan adalah rumah tempat memelihara dan merawat anak yatim atau yatim piatu. Peneliti telah melakukan observasi dan wawancara awal dengan Panti Asuhan Al-Husna, berdasarkan hasil wawancara, secara garis besar terdapat dua masalah yang mengemuka. Pertama adalah sumber finansial yang terbatas. Seluruh sumber finansial Panti Asuhan Al-Husna berasal dari donatur. Selain itu mereka tidak memiliki program atau kegiatan yang bersifat komersial. Problem kedua adalah kurangnya keterampilan para pengurus Panti Asuhan dalam bidang penyusunan laporan keuangan. Mayoritas latar belakang para pengurus adalah ibu rumah tangga dari masyarakat sekitar. Sehingga dari kondisi tersebut dalam hal pelaporan keuangan sangatlah sederhana, hanya berupa kas keluar dan kas masuk saja. Dalam rangka penerapan prinsip keterbukaandan akuntabilitas pada masyarakat, sebaiknya manajemen yayasan melakukan pembenahan administrasi, termasuk publikasi pertanggungjawaban laporan keuangan setiap tahun. Pada Panti Asuhan Yatim Piatu Al-Husna pihak bagian administrasi belum memahami bagaimana penerapan PSAK 45 mengenai organisasi nirlaba. Maka dari itu pihak administrasi yayasan ingin mengetahui bentuk laporan keuangan sesuai standar akuntansi sebagai pembelajaran agar bentuk laporan yayasan menjadi lebih baik.Mengingat adanya tuntutan atas akuntabilitas dan transparansi pada sektor publik serta pentingnya laporan keuangan yang disusun oleh organisasi nirlaba terutama pada Yayasan Panti Asuhan Yatim Piatu Al-Husna pembahasan secara mendalam mengenai laporan keuangan yang mengacu pada PSAK No. 45 perlu untuk dianalisis secara lebih mendalam lagi. Untuk itu perlu dilakukan penelitian lebih mendalam tentang penyusunan laporan keuangan dan penerapan PSAK No. 45 Tentang Laporan Keuangan Yayasan Panti Asuhan Yatim Piatu Al-Husna.

\section{Tujuan Khusus}

Tujuan dari laporan keuangan, yaitu untuk memberikan informasi kepada pihak yang membutuhkan tentang kondisi suatu perusahaan dari sudut angka-angka dalam satuan moneter (Fahmi, 2014: 26). Tujuan dari penelitian ini adalah untuk mendapatkan gambaran bagaimana sistem pencatatan dalam kebijakan akuntansi dan pelaporan keuangan yang diterapkan oleh Panti Asuhan AlHusna dan untuk menganalisis bagaimana proses akuntansi dalam penyusunan laporan keuangan entitas yang diteliti, kemudian dibandingkan dengan ketentuan sesuai dengan Pernyataan Standar Akuntansi Keuangan (PSAK) No. 45 tentang Lembaga Keuangan Pelaporan Keuangan organisasi nirlaba. 


\section{Urgensi Penelitian}

Penting untuk membuat pelaporan keuangan berdasarkan standar yang ditentukan, agar hasil dari laporan keuangan memenuhi prinsip keterbukaan dan akuntabilitas relevan dengan kegiatan kegiatan yang dilakukan oleh panti asuhan Al-Husna dan dapat dipertanggung jawabkan, sehingga terjadi kepercayaan dari donatur.

\section{TINJAUAN PUSTAKA}

\section{Laporan Keuangan}

Menurut Munawir (2010), laporan keuangan adalah hasil dari proses akuntansi yang dapat digunakan sebagai alat untuk berkomunikasi antara data keuangan atau aktivitas suatu perusahaan dengan pihak-pihak yang berkepentingan dengan data perusahaan. Martono (2010:52), berpendapat bahwa laporan keuangan yang baik dan akurat dapat memberikan manfaat antara lain dalam, pengambilan keputusan investasi, keputusan pemberian kredit, penilaian aliran kas, penilaian sumber ekonomis, melakukan klaim terhadap sumber dana, menganalisis perubahan yang terjadi terhadap sumber dana, dan menganalisis penggunaan dana. laporan keuangan adalah menyediakan informasi yang menyangkut posisi keuangan, kinerja serta perubahan posisi keuangan suatu perusahaan yang bermanfaat bagi sejumlah besar pemakainya dalam pengambilan keputusan ekonomi. Artinya, laporan keuangan merupakan alat untuk memperoleh informasi mengenai posisi keuangan dan hasil operasi yang telah dicapai oleh suatu perusahaan. Informasi tersebut nantinya akan digunakan sebagai bahan pertimbangan dalam pengambilan keputusan, baik oleh management perusahaan maupun pihak ekstern perusahaan (Dwi, 2016)

\section{Definisi Organisasi Nirlaba}

Definisi Organisasi Nirlaba Organisasi nirlaba adalah suatu organisasi yang bersasaran pokok untuk mendukung suatu isu atau perihal didalam menarik perhatian publik untuk suatu tujuan yang tidak komersil, tanpa ada perhatian terhadap hal-hal yang bersifat mencari laba (moneter). Organisasi nirlaba meliputi gereja, sekolah negeri, derma politik, rumah sakit dan klinik publik, organisasi politis, bantuan masyarakat dalam hal perundang-undangan, asosiasi professional, institut riset, museum, dan beberapa para petugas pemerintah. (Tinungki dan Rudy, 2014).

Organisasi nirlaba atau organisasi non profit adalah suatu organisasi yang bersasaran pokok untuk mendukung suatu isu atau perihal di dalam menarik perhatian publik untuk suatu tujuan yang tidak komersil, tanpa ada perhatian terhadap hal-hal yang bersifat mencari laba (moneter) (Haryono, 2019)

\section{Karakteristik Organisasi Nirlaba}

Menurut Ikatan Akuntansi Indonesia, IAI (2014) bahwa karakteristik entitas nirlaba berbeda dengan entitas bisnis. Perbedaan utama yang mendasar terletak pada cara entitas nirlaba memperoleh sumber daya yang dibutuhkan untuk melakukan berbagai aktivitas operasinya. Entitas nirlaba memperoleh sumber daya dari pemberi sumber daya yang tidak mengharapkan pembayaran kembali atau manfaat ekonomik yang sebanding dengan jumlah sumberdaya yang diberikan. Sebagai akibat dari karakteristik tersebut, dalam entitas nirlaba timbul transaksi tertentu yang jarang atau bahkan tidak pernah terjadi dalam entitas bisnis, contohnya penerimaan sumbangan, namun demikian, dalam praktik entitas nirlaba sering tampil dalam berbagai bentuk, sehingga sering kali sulit dibedakan dengan entitas bisnis pada umumnya. Karakteristik organisasi nirlaba berdasarkan PSAK No. 45 (2014) adalah sebagai berikut: a. Sumber daya entitas berasal dari para penyumbang yang tidak mengharapkan pembayaran kembali atau manfaat ekonomi yang sebanding dengan jumlah sumber daya yang diberikan. $b$. Menghasilkan barang dan atau jasa tanpa bertujuan memupuk laba dan jika suatu entitas menghasilkan laba, maka jumlahnya tidak pernah dibagikan kepada para pendiri atau pemilik entitas tersebut. c. Tidak ada kepemilikan seperti lazimnya pada organisasi bisnis, dalam arti 
bahwa kepemilikan dalam organisasi nirlaba tidak dapat dijual, dialihkan, atau ditebus kembali, atau kepemilikan tersebut tidak mencerminkan proporsi pembagian sumber daya entitas pada saat likuidasi atau pembubaran entitas.

\section{Metode Pencatatan Organisasi Nirlaba}

Di dalam akuntansi terdapat metode pencatatan yang membedakan cara pencatatan pendapatan dan biaya dalam laporan pendapatan dan biaya organisasi nirlaba secara signifikan. Adapun metode tersebut berdasarkan Niswonger de el, (1999) adalah : a. Cash Basis (basis kas) Pengertian biaya basis kas adalah seluruh pengeluaran yang dibayar oleh organisasi nirlaba. Dengan demikian, total biaya yang dilaporkan pada suatu periode adalah total pengeluaran yang tercatat pada buku bank organisasi nirlaba. Pengertian pendapatan adalah seluruh penerimaan uang kas oleh organisasi nirlaba. Pada akhirnya, surplus atau defisit merupakan selisih antara pendapatan dengan biaya. Bila digunakan basis kas, dapat diketahui secara cepat dengan menghitung berapa saldo kas yang ada pada akhir periode. b. Accrual Basis (basis akrual) Basis akrual melakukan pencatatan berdasarkan apa yang seharusnya menjadi pendapatan dan biaya organisasi nirlaba pada suatu periode. Apa yang seharusnya menjadi pendapatan organisasi nirlaba adalah semua pendapatan yang telah menjadi hak organisasi nirlaba terlepas apakah hak ini telah diwujudkan dalam bentuk penerimaan kas atau tidak.

\section{Akuntansi Yayasan}

Menurut UU No. 28 Tahun 2004 Tentang Perubahan Atas Undang-Undang Nomor 16 Tahun 2001 Tentang Yayasan, sebagai dasar hukum positif yayasan, pengertian yayasan adalah badan hukum yang kekayaannya terdiri dari kekayaan yang dipisahkan dan diperuntukkan untuk mencapai tujuan tertentu di bidang sosial, keagamaan, dan kemanusiaan. Kekayaan Yayasan baik berupa uang, barang, maupun kekayaan lain yang diperoleh Yayasan berdasarkan Undangundang ini, dilarang dialihkan atau dibagikan secara langsung atau tidak langsung, baik dalam bentuk gaji, upah, maupun honorarium, atau bentuk lain yang dapat dinilai dengan uang kepada Pembina, Pengurus dan Pengawas. Yayasan dapat melakukan kegiatan usaha untuk menunjang pencapaian maksud dan tujuaannya dengan cara mendirikan badan usaha dan ikut serta dalam suatu badan usaha.

\section{Laporan Keuangan Organisasi Nirlaba}

Laporan keuangan merupakan salah satu cara yang dapat digunakan atau dibuat oleh sebuah perusahaan atau entitas untuk memperlihatkan gambaran kondisi keuangan dari sebuah organisasi.. Menurut Ikatan Akuntansi Indonesia, IAI (2014:45.2), Laporan Keuangan untuk organisasi nirlaba terdiri dari laporan posisi keuangan, laporan aktivitas, laporan arus kas, dan catatan atas laporan keuangan. Dimana laporan keuangan entitas nirlaba ini berbeda dengan laporan keuangan entitas bisnis pada umumnya.

\section{Tujuan Laporan Keuangan Organisasi Nirlaba}

Menurut IAI, (2014:45.2) Tujuan utama laporan keuangan organisasi nirlaba adalah menyediakan informasi yang relevan untuk memenuhi kepentingan para penyumbang, anggota organisasi, kreditur, dan pihak lain yang menyediakan sumber daya bagi organisasi nirlaba. Secara rinci, tujuan laporan keuangan, termasuk catatan atas laporan keuangan sebagaimana tercantum dalam PSAK No.45 adalah untuk menyajikan informasi mengenai : 1. Jumlah dan sifat aset, liabilitas dan aset bersih suatu nirlaba 2. Pengaruh transaksi dan peristiwa yang mengubah nilai dan sifat aset bersih 3. Jenis dan jumlah arus masuk dan arus keluar sumber daya dalam satu periode dan hubungan antara keduanya 4. Cara entitas nirlaba mendapatkan dan membelanjakan kas, memperoleh pinjaman dan melunasi pinjaman, dan faktor lain yang berpengaruh terhadap likuiditasnya 5 . Usaha jasa entitas nirlaba 


\section{Unsur-Unsur Laporan Keuangan Organisasi Nirlaba}

PSAK No.45 Laporan keuangan organisasi nirlaba yang sesuai dengan PSAK No.45 meliputi: a. laporan posisi keuangan pada akhir periode b. laporan laporan aktivitas c. laporan arus kas untuk suatu periode pelaporan d. Catatan atas laporan keuangan.

\section{Laporan Posisi Keuangan}

Didalam PSAK Nomor 45 tahun 2014 dijelaskan bahwa Tujuan laporan posisi keuangan yaitu menyediakan informasi keuangan mengenai aktiva, kewajiban, dan aktiva bersih dan informasi mengenai hubungan di antara unsur-unsur tersebut pada waktu tertentu. Informasi dalam laporan keuangan lainnya, dapat membantu para penyumbang, anggota organisasi, kreditur dan pihak-pihak lain untuk menilai : 1. Kemampuan organisasi untuk memberikan jasa secara keberlanjutan 2. Likuiditas, fleksibilitas keuangan, kemampuan untuk memenuhi kewajibannya, dan kebutuhan pendanaan eksternal. Laporan posisi keuangan, termasuk catatan atas laporan keuangan, menyediakan informasi yang relevan mengenai likuiditas, fleksibilitas keuangan, dan hubungan antara aset dan kewajiban. Informasi tersebut umumnya disajikan dengan pengumpulan aset dan liabilitas yang memiliki karakteristik serupa dalam suatu kelompok yang relatif homogen. Sebagai contoh, organisasi biasanya melaporkan masingmasing unsur aset dalam kelompok yang homogen, seperti: a. Kas dan setara kas b. Piutang pasien, pelajar, anggota, dan penerima jasa yang lain c. Persediaan d. Sewa, asuransi, dan jasa lainnya yang dibayar di muka e. Surat berharga/efek dan investasi jangka panjang f. Tanah, gedung, peralatan, serta aktiva tetap lainnya yang digunakan untuk menghasilkan barang dan jasa.

\section{METODE}

\section{a. Jenis Penelitian}

Metode sebagaimana dalam kamus besar bahasa Indonesia adalah cara yang teratur dan terpikir baik-baik untuk mencapai maksud. Jenis penelitian ini menggunakan penelitian kualitatif. Penelitian kualitatif adalah penelitian yang bersifat deskriptif dan cenderung menggunakan analisis. Proses dan makna (perspektif subjek) lebih ditonjolkan dalam penelitian kualitatif. Dalam penelitian kualitatif peneliti bertolak dari data, memanfaatkan teori yang ada sebagai bahan penjelas, dan berakhir dengan suatu "teori". sedangkan untuk metode penelitiannya menggunakan metode deskriptif dimana metode ini merupakan metode non hipotesis sehingga dalam penelitiannya tidak perlu merumuskan hipotesis. Menurut Tinungki dan Rudy (2014), metode kualitatif deskriptif ini sifatnya menguraikan, menggambarkan, membandingkan suatu data dan keadaan serta menerangkan suatu keadaan sedemikian rupa sehingga dapat ditarik kesimpulan dari penelitian ini. Selain itu Metode penelitian kualitatif sebagaimana yang diungkapkan Bogdan dan Taylor (Maleong, 2011) sebagai prosedur penelitian yang menghasilkan data deskriptif berupa kata-kata tertulis atau lisan dari orangorang dan perilaku yang dapat diamati. Menurut Sugiyono (2018) bahwa penelitian kualitatif deskriptif adalah metode penelitian yang berlandaskan pada filsafat postpositivismeyang biasanya digunakan untuk meneliti pada kondisi objektif yang alamiah dimana peneliti berperan sebagai instrumen kunci. Guna menemukan hasil penelitian ini, maka peneliti menempuh beberapa langkah yaitu pengumpulan data, pengolahan data atau analisis data, penyusunan laporan dan penarikan kesimpulan. Proses ini dilakukan guna mendapatkan hasil penelitian secara objectif 


\section{b. Lokasi dan Subjek Penelitian \\ Lokasi Penelitian}

Lokasi dalam penelitian ini adalah Panti Asuhan Al-Husna yang terletak di komplek Bukit Pamulang Indah Kecamatan Paamulang Timur, Tangerang Selatan Provinsi Banten

Subjek Penelitian

Dalam penelitian ini subjek penelitian nya adalah ketua panti asuhan Al-Husna, bendahara, sekretaris dan para pengurus panti asuhan Al-Husna tersebut

\section{c. Jenis Data}

Data yang dikumpulkan untuk menunjang keakuratan penelitian ini, secara garis besar dapat dibagi menjadi:

i. Data Primer Data primer adalah data yang dikumpulkan, diolah, dan disajikan diperoleh langsung dari sumbernya (Sugiyono, 2018). Dimana peneliti mengumpulkan data langsung dari sumbernya dengan cara melakukan wawancara dan observasi.

ii. Data Sekunder Data sekunder adalah sumber yang tidak langsung memberikan data kepada pengiumpul data (Sugiyono, 2018). Disini peneliti menggunakan data keuangan atau pembukuan yang digunakan oleh Yayasan Panti Asuhan Al-Husna. Selain itu data kepengurusan yayasan baik tugas dan fungsi pembina, pengurus, dan pengawas.

\section{d. Teknik Pengumpulan Data}

Dalam penelitian kualitatif teknik pengumpulan data sangat diperlukan guna mendapatkan data dalam sebuah penelitian. Tanpa mengetahui teknik pengumpulan data maka peneliti tidak akan mendapatkan data sesuai dengan apa yang diharapkan. Menurut Sanusi (2014) pengumpulan data dapat dilakukan dengan berbagai cara seperti survei, observasi maupun dokumentasi. Teknik pengumpulan data yang digunakan dalam penelitian ini adalah sebagai berikut :

1) Survei Pendahuluan

Dalam melakukan penelitian ini, peneliti melakukan survei pendahuluan untuk mengetahui gambaran secara umum tentang profil yayasan dan melakukan wawancara kepada pihak yayasan untuk mengetahui tentang gambaran bentuk laporan keuangan dan menggali informasimengenai transaksi-transaksi apa saja yang dilakukan oleh yayasan sehingga lebih memudahkan penelitian. Nasution dalam Sugiyono (2018) menyatakan bahwa, observasi adalah dasar semua ilmu pengetahuan. Para peneliti hanya dapat bekerja berdasarkan data, yaitu fakta mengenai dunia kenyataan yang diperoleh melalui observasi. Adapun teknik ini dilakukan untuk mengetahui gambaran secara umum tentang profil yayasan. Metode ini menurut kejelian peneliti untuk dapat melihat adanya peristiwa atau kejadian yang dapat digunakan untuk menunjang penelitian. Pengamatan atau observasi merupakan suatu unsur penting dalam penelitian kualitatif, observasi dalam konsep sederhana adalah suatu proses atau kegiatan awal yang dilakukan oleh peneliti untuk bias mengetahui kondisi, realitas lapangan penelitian.

Dari berbagai macam observasi dimaksud tentunya memiliki manfaat dalam sebuah penelitian kualitatif. Oleh karena itu ,Patton (Sugiyono, 2018) mengungkapkan bahwa manfaat observasi adalah sebagai berikut:

a) Dengan observasi dilapangan peneliti lebih mampu memahami konteks data dalam keseluruhan situasi sosial, untuk mendapat pandangan yang holistik atau menyeluruh. 
b) Dengan observasi maka akan diperoleh pengalaman langsung, sehingga memungkinkan peneliti menggunakan pendekatan induktif, jadi tidak dipengaruhi oleh konsep atau pandangan sebelumnya. Pendekatan induktif membuka kemungkinan melakukan penemuan atau discovery. 3)Dengan observasi, peneliti dapat melihat hal-hal yang kurang dan tidak diamati oleh orang lain, khususnya orang yang berada dalam lingkungan itu karena telah dianggap biasa dan olehnya itu tidak terungkap dalam wawancara.

c) Dengan observasi, peneliti dapat menemukan hal-hal yang sedianya tidak akan terungkap oleh responden dalam wawancara karena bersifat sensitif atau ingin ditutupi karena dapat merugikan nama lembaga.

d) Dengan observasi, peneliti dapat menemukan hal-hal yang di luar persepsi responden, sehinggapeneliti memperoleh gambaran yang lebih komprehensif.

e) Melalui pengamatan lapangan, peneliti tidak hanya mengumpulkan data yang kaya, tetapi juga memperoleh kesan-kesan pribadi dan merasakan situasi sosial yang diteliti

\section{2) Survei Lapangan}

(a) Wawancara ( Interview )

Wawancara adalah proses untuk memperoleh data penelitian dengan cara tanya jawab, sambil bertatap muka antara penanya dan narasumber. Wawancara merupakan bagian penting dalam penelitian kualitatif sehingga peneliti dapat memperoleh data dari berbagai informan secara langsung. Penelitian kualitatif sangat memungkinkan untuk penyatuan teknik observasi dengan wawancara. Sebagaimana yang diungkapkan oleh Nasution (2003) bahwa dalam sebuah penelitian kualitatif observasi saja, belum memadai itu sebabnya observasi harus dilengkapi dengan wawancara. Teknik wawancara pada penelitian ini adalah wawancara tidak terstruktur. Wawancara tidak terstruktur, adalah wawancara yang bebas dimana peneliti tidak menggunakan pedoman wawancara yang telah tersusun secara sistematis dan lengkap untuk pengumpulan datanya (Sugiyono, 2018). Adapun wawancara ini dilakukan kepada pihak - pihak yang terkait, yaitu Pengasuh Yayasan dan Bendahara yang berkaitan tentang laporan keuangan Yayasan Panti Asuhan Al-Husna dan beberapa donator dari panti asuhan Al-Husna

(b) Dokumentasi

Dokumen merupakan catatan peristiwa yang sudah berlalu berupa berbentuk tulisan, gambar atau karya-karya monumental dari seseorang (Sugiyono, 2018). Studi dokumenter merupakan suatu metode atau teknik yang digunakan dalam penelitian kualitatif untuk mengungkapkan, mencari berbagai informasi dari sumber-sumber yang berkaitan dengan masalah penelitian. Metode Dokumentasi adalah metode pencarian dan pengumpulan data mengenai bahan -bahan informasi yang dikeluarkan suatu lembaga yaitu data yang terkait dengan laporan keungan Yayasan Panti Asuhan Yatim Piatu Al-Husna. Adapun pendokumentasian pada penelitian ini dilakukan dengan cara mengumpulkan data mengenai bahan - bahan informasi yang disusun oleh yayasan yaitu data laporan keungan Yayasan Panti Asuhan Siti Masyitoh Besuki Situbondo.

\section{e. Teknik Analisis Data}

Menurut sugiyono (2018), analisis data merupakan proses mencari dan menyusun data yang diperoleh dari hasil wawancara, catatan lapangan, ataupun bahan-bahan lainnya yang secara sistematis mudah dipahami dan temuannya dapat diinformasikan kepada orang lain. 
Dalam penelitian kualitatif, tehnik analisis data diperoleh dari berbagai sumber dengan menggunakan tehnik pengumpulan data. Untuk menjawab rumusan masalah, maka metode analisis yang digunakan adalah metode analisis deskriptif kualitatif. Tahapan -tahapan dalam penelitian ini adalah :

1) Mengumpulkan data laporan keuangan Yayasan Panti Asuhan Al-Husna

2) Mendeskripsikan laporan keuangan melalui data yang diperoleh serta melalui wawancara dengan pihak yang terkait mengenai informasi yang dilaporkan dalam laporan keuangan Yayasan Panti Asuhan Al-Husna.

3) Membuat rekontruksi Laporan Keuangan yayasan yang sesuai dengan PSAK 45

4) Menyajikan laporan keuangan Yayasan Panti Asuhan Al-Husna yang sudah sesuai dengan PSAK no.45

\section{HASIL DAN PEMBAHASAN}

Panti asuhan Al-Husna setelah kami lakukan penelitian, memiliki aktivitas yang sederhana dan sedikit. Hal ini dikarenakan panti asuhan memang hanya mempunyai aktivitas yang sedikit, tidak ada memiliki panti atau tempat untuk menampung anak asuh mereka. Mereka hanya menyantuni tiap bulan para anak asuh mereka. Berikut hasil dari penyusunan laporan keuangan kami susun

1) Laporan posisi keuangan berdasarkan PSAK 45

\begin{tabular}{|l|l|}
\hline \multicolumn{2}{|c|}{$\begin{array}{c}\text { Yayasan Panti Asuhan Al Husna } \\
\text { LAPORAN POSISI KEUANGAN } \\
\text { Per 31 Desember 2019 }\end{array}$} \\
\hline ASET & \\
aset lancar & $50.374 .557,73$ \\
\hline Total asset & $50.374 .557,73$ \\
\hline $\begin{array}{l}\text { LIABILITIES DAN } \\
\text { ASET NETO }\end{array}$ & \\
tidak terikat & 37.024 .558 \\
Terikat & 13.350 .000 \\
\hline $\begin{array}{l}\text { Total liabilitas dan aset } \\
\text { neto }\end{array}$ & 50.374 .558 \\
\hline
\end{tabular}


2) Laporan aktivitas

\begin{tabular}{|c|c|}
\hline $\begin{array}{r}\text { YAYASAN PANTI ASU } \\
\text { LAPORAN AK } \\
\text { PER } 31 \text { DESEM }\end{array}$ & HUSNA \\
\hline Sumbangan donasi & 171.682 .350 \\
\hline Pendapatan zakat & 11.250 .000 \\
\hline pendapatan lain lain & 7.508 .783 \\
\hline & 190.441 .133 \\
\hline biaya sekolah & 120.965 .575 \\
\hline biaya sewa tempat & 10.000 .000 \\
\hline biaya matrai & 6.000 \\
\hline biaya hadiah hafal Qur'an & 1.000 .000 \\
\hline biaya bantuan insidentil & 315.000 \\
\hline biaya konsumsi & 1.550 .000 \\
\hline biaya tunjangan hari raya & 5.400 .000 \\
\hline biaya pembuatan kerajinan & 1.500 .000 \\
\hline biaya keperluan bazar & 500.000 \\
\hline biaya lain lain & 12.180 .000 \\
\hline & 153.416 .575 \\
\hline kenaikan aset neto tidak terikat & 37.024 .558 \\
\hline kenaikan aset neto terikat & 13.350 .000 \\
\hline $\begin{array}{l}\text { kenaikan aset neto } \\
\text { aset neto pada awal tahun }\end{array}$ & 50.374 .558 \\
\hline aset neto pada akhir tahun & 50.374 .558 \\
\hline
\end{tabular}


3) Laporan arus kas

\begin{tabular}{|c|c|}
\hline $\begin{array}{r}\text { YAYASAN PANTI ASUHA } \\
\text { LAPORAN ARUS } \\
\text { Per } 31 \text { Desember }\end{array}$ & \\
\hline Sumbangan donasi & 171.682 .350 \\
\hline Pendapatan zakat & 11.250 .000 \\
\hline pendapatan lain lain & 7.508 .783 \\
\hline & 190.441.133 \\
\hline biaya sekolah & 120.965 .575 \\
\hline biaya sewa tempat & 10.000 .000 \\
\hline biaya materai & 6.000 \\
\hline biaya hadiah hafal quran & 1.000 .000 \\
\hline biaya bantuan insidenti & 315.000 \\
\hline biaya konsumsi & 1.550 .000 \\
\hline biaya thr & 5.400 .000 \\
\hline biaya pembuatan kerajinan & 1.500 .000 \\
\hline biaya keperluan bazar & 500.000 \\
\hline biaya lain lain & 12.180 .000 \\
\hline & 153.416 .575 \\
\hline kas bersih yang diterima (digunakan) & 37.024 .558 \\
\hline untuk aktifitas operasi & \\
\hline Aliran kas dari aktivitas investasi & \\
\hline untuk biaya sewa tempat & 10.000 .000 \\
\hline untuk biaya seragam & 3.350 .000 \\
\hline kas bersih yang diterima untuk investasi & 13.350 .000 \\
\hline kas bersih yang diterima (digunakan) & 50.374 .558 \\
\hline untuk aktifitas operasi & \\
\hline kas dan setara kas awal tahun & $29.467 .349,69$ \\
\hline kas dan setara kas akhir tahun & $79.841 .907,42$ \\
\hline
\end{tabular}

4) Catatan atas laporan keuangan

Catatan atas laporan keuangan merupakan catatan yang menjelaskan mengenai gambaran umum organisasi, ikhtisar kebijakan akuntansi, serta penjelasan pos-pos laporan keuangan dan informasi penting lainnya. Dilihat dari rekonstruksi laporan keuangan Panti asuhan Al Husna yang dibuat belum mengacu pada PSAK No. 45. Dengan laporan keuangan yang telah ditampilkan dan dipublikasi seperti ini memang cukup mudah dipahami oleh masyarakat umum (donator), karena sudah cukup transparan dalam melaporkan keuangan kepada masyarakat. Laporan keuangan Panti Asuhan Al-Husna diterbitkan dalam periode setiap tahun. Laporan keuangan setiap tahun ditujukan untuk pihak internal dan untuk masyarakat umum (donatur) sebagai bentuk akuntabilitas. Catatan atas laporan keuangan meliputi penjelasan naratif atau rincian jumlah yang tertera dalam laporan posisi keuangan, laporan aktivitas, dan laporan arus kas serta informasi tambahan seperti kewajiban kontinjensi dan komitmen. Catatan atas laporan keuangan juga mencakup informasi yang diharuskan dan dianjurkan untuk diungkapkan dalam Pernyataan Standar Akuntansi Keuangan serta pengungkapan-pengungkapan lain yang diperlukan untuk menghasilkan penyajian laporan keuangan secara wajar 


\section{SIMPULAN}

Dari hasil penelitian ini, peneliiti menarik kesimpulan bahwa penyusunan laporan keuangan yang dilakukan selama ini oleh Panti Asuha Al Husna sangatlah sederhana. Dan peneliti pada kesempatan ini menyusunkan laporan keuangan berdasarkan PSAK 45 tentang laporan keuangan organisasi Nirlaba. Dimana terdiri dari Laporan Posisi Keuangan, Laporan Aktivitas, Laporan Arus Kas dan Catatan Laporan Keuangan. Untuk transaksi nya sendiri panti Asuhan Al-Husna termasuk sederhana, sedikit aktivitas, karena mereka hanya menyantuni tiap bulan para anak asuh nya, tapi tidak di tampung dalam sebuah tempat, anak asuh nya masih tinggal di keluarga mereka masing masing.

Diharapkan untuk selanjutnya para pengurus dapat mempraktekkan penyusunan laporan keuangan berdasarkan PSAK 45 yang sesuai dengan organisasi nirlaba mereka agar tercipta laporan keuangan yang akuntabilitas dan transparan. Sehingga pada akhirnya diharapkan mampu menarik donator lebih banyak lagi.

\section{DAFTAR PUSTAKA}

Afifah, Machfiana. 2019. Implementasi PSAK no.45 pada Organisasi Nirlaba (Studi Kasus pada Poliklinik Kesehatan 05.09.02 Lumajang). Thesis. Institusional Repository STIE Widya Gama Lumajang.

Anwar, Sanusi. 2014. Metodologi Penelitian Bisnis. Jakarta: Salemba Empat.

Dinanti, Aldila \& Ginanjar Adi Nugraha. 2018. Pelaporan Keuangan Organisa Nirlaba. Jurnal Ekonomi, Bisnis dan akuntansi (JEBA) Volume 20 Nomor 01 Tahun 2018.

Dwi, Kurnia. (2016). Analisis Laporan Keuangan Dalam Mengukur Kinerja Perusahan Pada Pt. Ricky Kurniawan Kertapersada (Makin Group) Jambi . Jurnal Valuta Vol 2 No 2, Oktober 2016, 190-207

Fahmi, Irham. 2014. Analisis Kinerja Keuangan. Alfabeta. Bandung.

Haryono, Fini. 2019. Evaluasi Penerapan PSAK no 45 Tentang Pelaporan Keuangan Entitas Nirlaba pada Jemaat GMIM Sion Teling Sentrum Manado. Universitas Sam ratulangi Manado. Jurnal EMBA Vol.7 No.1 Januari 2019, Hal. 981 - 990

Ikatan Akuntan Indonesia. 2015. Pernyataan Standar Akuntansi Keuangan No. 45 (Revisi 2015) TentangPelaporan Keuangan Entitas Nirlaba. Jakarta. Ikatan Akuntansi Indonesia

Ikatan Akuntan Indonesia. 2014. Pernyataan Standar Akuntansi Keuangan Nomor 45 (Revisi 2014) tentang Pelaporan Keuangan Entitas Nirlaba. Jakarta. Ikatan Akuntansi Indonesia. Balai Pustaka,1990. Kamus Besar Bahasa Indonesia. Depdikbud, Jakarta.

Munawir, S. 2010. Analisis Laporan Keuangan. Yogyakarta: Liberty

Martono, Agus. 2010. Manajemen Keuangan. Yogyakarta: Ekonesia.

Moleong, L.J. 2011. Metodologi Penelitian Kualitatif Edisi Revisi. Bandung: PT. Remaja Rosdakarya.

Nasution. (2003). Metode Penelitian Naturalistik Kualitatif. Bandung: Tarsito.

Niswonger, C. Rollin, dkk. 1999. Prinsip-Prinsip Akuntansi. Jilid 1. Edisi 19. Penerbit Erlangga: Jakarta.

Peraturan Pemerintah. 2004. Undang undang No. 28 yang mengatur tentang perubahan atas Undang-Undang Nomor 16 tahun 2001 tentang Yayasan. Sekretariat Negara, Jakarta.

Sugiyono. 2018. Metode Penelitian Kuantitatif, Kualitatif, dan R\&D. Alfabeta. Bandung:

Tinungki, Angelia Novrina Meilani, and Rudy J. Pusung. "Penerapan Laporan Keuangan Organisasi Nirlaba Berdasarkan PSAK No. 45 pada Panti Sosial Tresna Werdha Hana." Jurnal EMBA: Jurnal Riset Ekonomi, Manajemen, Bisnis dan Akuntansi 2, no. 2 (2014). 